\title{
ULTRASTRUCTURE OF THE ENAMEL LAYER IN DEVELOPING TEETH OF THE SHARK CARCHARHINUS MENISORRAH
}

\author{
N. E. KeMP and J. H. PARK \\ Department of Zoology, The University of Michigan, Ann Arbor, Michigan 48104, U.S.A., and \\ College of Dentistry, Yonsei University, Seoul, Korea
}

\begin{abstract}
Summary-The first two rows of teeth at the posterior end of the dental lamina in a $60 \mathrm{~cm}$ specimen of Carcharhinus menisorrah were uncalcified, but calcification had begun in the tooth cap layer at the tips of third-row teeth. Enamel crystals developed within hollow enameline fibrils (tubules) which polymerized beneath the basement menbrane underlying ameloblasts. Vesicles containing fine granules were present in the apical cytoplasm of ameloblasts in tooth buds prior to calcification. Fine granular material accumulated extracellularly between ameloblasts and basement membrane, and also in the enameline matrix on the pulpal side of the basement membrane. The morphology suggests that ameloblasts secrete a granular precursor for the mineralizing enameline fibrils. Enamel crystals with their fibrous coatings were tightly packed in mineralizing zones. Crystals became indefinitely long and equilaterally hexagonal in cross section. They were aligned in parallel within bundles of fibrils interwoven in the mineralizing zones. Odontoblast processes and myelinated nerve fibres penetrated into the cap layer between mineralizing zones. Giant fibres with a banding periodicity of $14.5 \mathrm{~nm}$ occurred in the partitioning matrix between zones of mineralization. Their origin and nature are uncertain. Conventional collagen fibrils developed in the connective tissue within the base of the tooth, and in dentine after it began to differentiate. Crystals of mineralized dentine were needle-shaped as in mammals. The cap layer of the shark's tooth is considered to be composed of tubular enamel in which the mineralized zones are probably homologous with mammalian enamel, but which is penetrated by odontoblast processes of mesodermal origin.
\end{abstract}

\section{INTRODUCTION}

The gnathic teeth of sharks develop in a succession of serrated ranks following the contour of the jaws (Peyer, 1968). Tooth primordia originate in the dental lamina, an outgrowth of the oral epithelium extending posteriad into the lamina propria of the oral mucosa overlying the palatoquadrate and mandibular cartilages (Daniel, 1934). The tooth bud begins at the posterior end of the dental lamina as a dome of ectodermal epithelial cells enclosing a dental papilla derived from mesoderm. As the tecth elongate, they become pointed in carcharhinid sharks and bend basally so that their apices point backward toward the pharynx. Older, more anterior teeth overlap those behind. Calcification begins around the tips of teeth toward the rear of the dental lamina and becomes progressively heavier as the teeth grow larger in more anterior rows.

Poole (1967), Moss (1968), Peyer (1968), Salomon 1969), Grady (1970) and Garant (1970) have recently discussed the continuing controversy over the homology between the mineralized layers of the teeth in sharks and higher vertebrates. One group of comparative odontologists, including Lison (1949) and Moss (1968) have supported Hertwig's (1874) contention that the hard outer cap of sharks' teeth is true enamel, derived from ectoderm as in mammals. An opposing school (Röse, 1898; Weidenreich, 1926; Bargmann, 1937; Schmidt, 1940; Kvam, 1950; Peyer, 1968; Grady, 1970) have upheld Owen's $(1840-1845)$ belief that sharks lack ectodermally derived enamel. The latter group have maintained that the outer layer of elasmobranch teeth is a product of mesodermal cells of the dental papilla and hence is a modified kind of dentine. Names they have ascribed to the cap layer include: vitrodentine (Röse, 1898), durodentine (Schmidt, 1940), mesodermal enamel (Kvam, 1950) and peripheral initial zone (Peyer, 1968).

There are obvious differences between the outer cap of selachian teeth and the enamel of mammalian teeth. Kerr (1955) lists three: (1) the organic base is fully formed before calcification begins in shark teeth. (2) the matrix is penetrated by cytoplasmic processes from pulp cells and "reticular fibres from basement membrane". (3) this matrix of the outer cap is the first region of the tooth to calcify. Jaekel (1891) nevertheless concluded that shark teeth are covered with a primitive kind of enamel which he called Placoinschmelz or placoid enamel. Tomes (1898) likewise concluded that shark teeth possess "an early form of enamel". In a similar vein, Orvig (1951) has suggested that the enamel-like tissues of lower vertebrates may represent "enamel of an earlier phylogenetic stage of develop- 
ment". Thomasset (1930) has proposed that both ectoderm and mesoderm contribute components for shark tooth enamel, an explanation deemed likely by Lison (1949) and Kerr (1955). The same thought has been expressed by Poole (1967), who asserts that "there is some reason for supposing that the highly calcified tissues covering dentine are the result of the joint activity of the dental cap and the dental papilla, the relative roles played by the two structures differing in the different groups of vertebrates". He and Orvig (1967) advocate use of the term "enameloid" as a non-specific designation of the character of the tooth cap in vertebrates below reptiles, pending clarification of its germ layer of origin.

Ultrastructural analysis of mammalian teeth has revealed that decalcified bovine and rat enamels (Travis, 1968; Jessen, 1968) possess tubular compartments, elliptical in cross section, within which the long apatite crystals of prisms or interprisms develop. Mammalian dentine. by contrast. mineralizes like bone by development of short. needle-like crystals in close association with collagen fibrils (Frank, 1966). Shark dentine mineralizes in the same manner (Garant, 1970). Biochemical analysis has shown (Levine $t$ al. 1966) that the principal protein of shark tooth enamel is not collagen, although Moss, Jones and Piez (1964) have reported what they called "ectodermal" collagen in the crown of sharks' teeth.

The case for the homology of enamel in elasmobranchs and mammals rests squarely on the question of the origin of the organic matrix (Garant, 1970). According to commonly accepted definitions (Lison. 1949). enamel is the hard tissue of ectodermal origin produced by ameloblasts; dentine is of mesodermal origin. produced by odontoblasts. If both ameloblasts and odontoblasts secrete components of the cap layer in shark teeth and only ameloblasts in mammalian teeth, it may be argued that enamel is not homologous in the two groups. One should take into consideration though that ameloblast processes penetrate deeply into the "tubular enamel" of marsupials (Tomes, 1897 . Lester, 1970) and that odontoblast processes apparently extend into the tubular enamel of many teleost fishes (Tomes, 1897: Mummery. 1917: Thomasset. 1930: Peyer, 1968). In this paper, we will describe the structure of the tubular enamel in developing sharks teeth and consider how both ameloblasts and odontoblasts may contribute components of the cap layer matrix.

\section{MATERIALS AND METHODS}

A $60 \mathrm{~cm}$ specimen of Carcharhinus menisorrah caught at Eniwetok Atoll. Marshall Islands, was the source of the jaw tissue used in this study. The shark was one of several delivered live to the Eniwetok Marine Biological Laboratory and kept for a few days in a concrete tank supplied with circulating sea water.

Rectangular blocks including the tooth-bearing oral mucosa, jaw cartilage, connective tissue and skin were excised from upper and lower jaws and fixed in Bouin's fluid for subsequent preparation of paraffin sections for light microscopy. Strips of oral mucosa with attached teeth were dissected from similar blocks of jaw tissue and fixed in 6.25 per cent glutaraldehyde. $0.15 \mathrm{M}$ phosphate buffered at $\mathrm{pH} 7 \cdot 4$, for subsequent processing for electron microscopy. The strips were trimmed to the width of a single row of functional and replacement teeth. Several days later, the tooth-bearing strips were washed with 7.5 per cent sucrose and postfixed in ice-cold 1 per cent $\mathrm{OsO}_{4}$ in acetate-Veronal buffer at pH 7.4. The fixed fragments were dehydrated and embedded in Maraglas in flat plastic containers.

Photographs of jaw fragments were taken with $35 \mathrm{~mm}$ Lxacta and Nikon canneras. Bouin-fixed blocks were washed in water, decalcified overnight in Decal (Scientific Products, Evanston, Illinois), dehydrated in 95 per cent ethanol. cleared in amyl acetate and cmbedded in $56.58 \mathrm{C}$ Tissuemat. Sections were cut at $10 \mu \mathrm{m}$ and stained with haematoxylin and eosin or with Heidenhain's azan stain. Photomicrographs were taken on 4 in $\times 5$ in panchromatic film with a Spencer photomicrographic camera. Teeth embedded in Maraglas were sectioned with a Dupont diamond knife in an LKB Ultrotome. Thin sections were mounted on uncoated, 200-mesh, copper grids and stained with a saturated solution of uranyl acetate. Electron micrographs wore taken with an RCA EMU-3E electron microscope operating at $50 \mathrm{kV}$.

\section{RESLLTS}

The teeth of Carcharhimus menisorrah are triangular with serrated edges. and with a prominent main cusp flanked by lower lateral cusps. They develop within the oral pocket formed by a fold of the oral mucosa. A block of jaw tissue with the inner wall of the oral pocket removed (Fig. 1) illustrates a single file from the eight rows of teeth in the lower jaw of this species. The most anterior, heavily calcified teeth are erected for biting, whereas replacement teeth project posteriad and overlap those behind. Counting from the posterior end, the first two rows in our specimen were uncalcified, but calcification had begun at the tips of teeth in the third row.

\section{Microscopic observations}

Early stages of tooth development were observed towards the posterior end of the dental lamina, a shelf of stratified squamous epithelium extending from the oral mucosa covering the anterior margin of the jaw and embedded in connective tissue of the lamina propria. The first step was the development of a rounded evagination in the underside of the dental lamina (Fig. 2). Cells of this dome were cuboidal. Next the tooth bud elongated to the shape of a cone (Fig. 2). At this stage its epithelial cells had differentiated into columnar ameloblasts, graduating in height to the tallest apically. These cells surrounded a core of connective tissue cells constituting the dental papilla. Matrix of the 
enamel zone beneath apical ameloblasts stained pink with eosin and light blue with the aniline blue of Heidenhain's azan stain. As the enameline matrix developed further in a growing tooth (Fig. 3), it was traversed by linear structures which included obliquely oriented odontoblast processes from peripheral cells of the dental papilla and also fibres oriented perpendicular to the tooth surface. The latter stained blue with aniline blue.

Matrix of dentine was first deposited toward the base of the tooth after deposition of the enameline matrix was well advanced (Fig. 4). Initially the layer of dentine was thin beneath the basal enamel but broadened in the tooth base below the level of elongated ameloblasts. Later the dentine thickened and underlay all the enamel. The pulp cavity of a heavily mineralized tooth was reduced to a narrow central tube surrounded by orthodentine in the main cusp. Within the base of the tooth, the dentine was trabecular with the pulp cavity subdivided. Where the mineralized tooth was capped with enamel, odontoblast processes extended through the dentine and continued into the enamel layer.

\section{Electron microscope observations}

The outer enamel of the main cusp of a partly mineralized tooth (Fig. 5) contained zones of mineralization, which in section are called palisades according to Garant's (1970) terminology. These zones were packed with elongate enamel crystals coursing in paths within which the crystals were parallel. Between the palisades of enamel were soft tissue partitions which contained unit fibrils about $10 \mathrm{~nm}$ dia and also giant fibres crossbanded with a periodicity of about $14.5 \mathrm{~nm}$. Cytoplasmic elements between palisades and also penetrating into them (Fig. 5) included myelinated nerve fibres, odontoblast processes and regressing remnants of such processes.

In sections of cone-shaped teeth before mineralization had begun (Fig. 6), ameloblasts, matrix and cells of the dental papilla were separated by a finely granular basement membrane. The apical cytoplasm of ameloblasts at this stage had a granular texture and contained profiles of smooth endoplasmic reticulum, including cisternae and vesicles. Fine granular material was also seen extracellularly in the electron-lucent zone between ameloblasts and basement membrane. Cytoplasmic elements of the dental papilla included myelinated nerve processes with ensheathing Schwann cells and connective tissue papilla cells. In the matrix surrounding these cytoplasmic elements were three kinds of fibres: (1) unit fibrils, (2) giant fibres of presumptive interpalisadal zones, oriented perpendicular to the basement membrane, and (3) fibrils about $15 \mathrm{~nm}$ dia running in various directions within presumptive palisadal zones.

At an early stage of mineralization of the enamel layer (Fig. 7), the apical ends of ameloblasts had become folded to form apical crypts. Granular material in the crypts had the same density as the basement membrane. Apical vesicles containing similar granular material were abundant in the apical cytoplasm of ameloblasts. Apical vesicles were often in contact with the plasma membrane and sometimes appeared to be fused with it. Clustering of vesicles around the bases of apical crypts suggests that the crypts formed through eruption of many apical vesicles around localized regions of the plasma membrane.

A conspicuous feature of the mineralizing enameline matrix (Fig. 7) was that developing enamel crystals occupied the hollow interiors of fibrils (tubules) which we call enameline fibrils. A few fibrils and enclosed crystals were seen in the sparsely mineralized zonc beneath the basement membrane, but the bulk of the fibrils and crystals were densely packed in the mineralizing zone below this region of sparse mineralization. The abundance of granules and fine fibrils in the sparsely mineralized zone suggested that this was a region of assembly of the precursor units which aggregate into enameline fibrils.

Not all of the enameline fibrils in the mineralizing zone (Fig. 7) had begun to mineralize. The tubular character of those containing crystals, however, was seen clearly at higher magnification (Fig. 8). Walls of the tubules showed granular subunits in cross section. Diameters of the tubules and widths of their contained crystals were somewhat variable at the early stage of crystal growth depicted in Fig. 8. Even these young crystals had a polygonal outline viewed transversely. In the longitudinal direction the crystals developed as long threads of indefinite length (Fig. 9). We did not observe breaks which would indicate a standard length. Well-developed crystals were equilaterally hexagonal in cross section (Fig. 10).

Giant fibres in the soft tissue of the tooth cap are illustrated in Figs. 5, 6, 10 and 11. They appeared to form by aggregation of fibrillar subunits. Individual protofibrils of developing fibres were clearly visible in cross section (Fig. 10). The major periodicity displayed by the dark bands in giant fibres (Fig. 11) was $14.5 \mathrm{~nm}$. There was a lighter band within each period. We did not observe collagen fibrils with a periodicity in the vicinity of $64 \mathrm{~nm}$ in the outer portion of the developing enamel layer, but they were present toward the dentine-enamel junction and within the dentine of mineralizing teeth. Unit fibrils and giant fibres characterized the interpalisadal matrix of the enamel layer, whereas deeper in the tooth there appeared to be a zone of overlap where giant fibres and collagen fibrils occurred together.

\section{DISCUSSION}

Our investigation has revealed that the cap layer of Carcharhinus contains enamel with crystals like those in mammalian teeth, although the mineralized component is permeated by soft tissue structures, including nerve endings, fibrous matrix and odontoblastic processes. This type of enamel in Mummery's (1917) terminology is "tubular enamel". It is present in some 
teleost fishes, in recent marsupials, and in some fossil nontherians (Tomes, 1897; Mummery, 1917; Moss. 1968; Lester, 1970). The "tubules" appear to be occupied by ameloblast processes in marsupials. Odontoblast processes extending into the enamel layer may be considered a primitive vertebrate characteristic. Enamel spindles, which are expanded continuations of dentinal tubules within the enamel layer (Gustafson and Gustafson, 1967), are probably persisting vestiges of the extensive tubulation in lower vertebrates.

Previous workers have generally spoken of "enamel" or "cap layer" synonymously, or have substituted for enamel another name such as vitrodentine, durodentine. mesodermal enamel. enameloid, or initial peripheral zone. Considering the cap layer in its entirety, we favour the view of Thomasset (1930). Lison (1948) and Kerr (1955) that both ectoderm and mesoderm contribute to it. Considering as "enamel" only the mineralized portion of the tooth cap, however, we believe that previous investigators (Moss et al., 1964 : Moss, 1968) who have contended that elasmobranch enamel is of ectodermal origin are probably correct. Garant (1970) prefers to call the tooth cap an "enameloid layer" while its origin from ectoderm or mesoderm remains in question.

What are the arguments against believing that shark tooth enamel is derived from ectoderm? According to Peyer (1968), shark teeth lack "true" enamel because they do not meet the following criteria for enamel in reptiles and mammals: (1) "formed by cells of the inner epithelium, the ameloblasts", (2) formed outside the mesodermal area. (3) direction of growth centrifugal. (4) hardened by mineralization of cell processes of ameloblasts. (5) shows characteristic negative bireliingence. Peyer recognizes that the extent of the glassy cap layer coincides with the distribution of elongate ameloblasts during growth but ascribes to these cells purely formative. inductive or protective roles. He denies that they are secretory. In his view the tooth cap is a product of odontoblasts and should be considered modified dentine. Grady (1970) agrees with Peyer and advances his own list of five principal objections to recognition of the shark tooth cap as "true" enamel: (1) the order of mineralization of outer and inner calcified layers is reversed in sharks and mammals. (2) the cap matrix is permeated by odontoblast processes: (3) "cells of the inner dental epithelium lose all basophilia at the time of matrix formation and consequently do not give the appearance of cells synthesizing protein for the organic matrix". (4) the mineralized cap of the shark's tooth develops on the pulpal side of the basement membrane of the dental epithelial cells. (5) the front of apposition of new material appears to be on the inner side of the cap matrix, i.e. the direction of growth appears to be centripetal.

Despite these objections, our study implicates the ameloblasts as the probable source of the enameline fibrils of shark tooth enamel. If this be true. then growth of the tooth cap is centrifugal. Ultrastructural details of shark ameloblasts at various stages of tooth growth have not been published (Garant, 1970), but some of our observations support the hypothesis that the organic matrix for shark enamel is a product of ameloblast secretion. First. vesicles containing dense material are present in the apical cytoplasm of amcloblasts (Figs. 6, 7). Second, these vesicles appear to fuse with the plasma membrane and secrete their contents extracellularly. Third, electron-dense granular material accumulates in apical crypts of ameloblasts outside the basement membrane. Fourth. dense granular material also accumulates below the basement membrane and appears to be the precursor for enameline fibrils (tubules) polymerizing in the matrix beneath them. Fifth, the enameline fibrils are clearly different from conventional collagen fibrils, and elongated enamel crystals develop within them as in mammalian enamel. The enamel layer, and its constituent fibrils and crystals. appear to grow by centrifugal apposition. The only weak link in this chain of circumstantial evidence is that we have not demonstrated positively that an ameloblast secretory product traverses the basement membrane.

Mammalian ameloblasts are known to secrete the organic matrix of enamel (Fearnhead. 1961: Rönnholm. 1962, a.b,c: Frank and Nalbandian. 1967 : Kallenbach, 1970, 1971; Reith, 1970; Warshawsky, 1971: Weinstock and Leblond, 1971). Shark ameloblasts lack processes like the Tomes processes of mammals. hut it has been demonstrated that mammalian ameloblasts may begin to secrete the inner prismless layer of mineralizing enamel matrix even before Tomes processes develop (Rönnholm, 1962b: Warshawsky, 1971).

It is true that shark enamel begins to calcify before dentine. but this reversal of the mammalian sequence may indicate merely that elasmobranchs and mammals differ in the timing of activity of ameloblasts and odontoblasts. Structurally the mineralized zones of shark enamel are like those of mammalian enamel rather than mammalian dentine. Shark dentine, on the other hand. closely resembles mammalian dentine. The sequence of ossification of bones and mineralization of teeth varies among species (Kemp and Hoyt. 1969), and determinations of homology must be based on developmental anatomy rather than exact chronology.

\section{Structure of shark enamel}

The principal protein of the matrix of mammalian enamel has been reported as keratin-like (Pautard. 1961: Rönnholm. 1962c; Piez. 1962; Glimcher et al.. 1964). Levine et al. (1966) have reported that the protein of shark tooth enamel is not collagenous, although Moss et al. (1964) have characterized this protein as an "ectodermal, invertebrate-like collagen" different from mesodermal collagen. The enameline fibrils of $\mathrm{Car}$ charhinus cnamel are certainly distinct from conventional collagen fibrils.

Shark enamel shares with mammalian enamel the pattern of crystal development within the interior of 
hollow enameline fibrils (tubules) (Travis, 1968). The tubules appear to expand to accommodate increasing girth of crystals in the shark tooth. Previous workers have demonstrated that shark enamel crystals resemble those of mammalian enamel in their long, narrow shape and their orientation parallel to one another in bundles (Schmidt, 1940; Trautz, Klein and Addelston, 1952; Frank, Sognnaes and Kern, 1960; Glas and Omnell, 1960; Souza and Sasso, 1961; Sasso and Santos. 1961). Human enamel crystals (Frazier, 1968) and those of the rat (Nylen, Eanes and Omnell. 1963) are slightly flattened hexagons in cross section. Bovine enamel crystals are rectangular as they develop within elliptical tubules (Travis, 1968; Jessen, 1968). Shark enamel crystals become equilaterally hexagonal, according to Garant's (1970) work with Squalus and our results with Carcharhinus. Glas (1962) has presented evidence that shark tooth enamel is more like fluoroapatite than like hydroxyapatite. Possibly fluoride content affects the shape of the crystals. Another possibility is that crystals of shark enamel are free to grow equilaterally, whereas mammalian crystals and the tubules surrounding them may be subjected to uni-directional compression against dentine or previously deposited enamel. Crystals of dentine are short and needle-shaped both in mammals and sharks (Veis, Spector and Carmichael, 1969; Frank and Nalbandian, 1967; Garant, 1970).

\section{Giant fibres in the shark tooth cap}

The presence of odontoblast processes extending into the enamel layer of sharks' teeth is the principal reason why many investigators have concluded that this layer is modified dentine, derived from odontoblasts. Kerr (1955) described reticular fibres oriented perpendicular to the tooth surface in the enamel layer, and also long or short collagenous fibres accompanying the odontoblast processes in this layer. He observed that the fine reticular fibres lead into coneshaped enlargements attached to the basement membrane beneath the ameloblasts. It is probable that these enlargements correspond to the giant fibres we have observed electron microscopically (Figs. 5, 6, 10 , 111.

Our first interpretation of the giant fibres and the unit fibrils from which they polymerize was that they are collagenous (Kemp and Park, 1969). Superficially they resemble the actinotrichia of teleost fins (Kemp and Park, 1970). We estimated that the periodicity of the giant fibres was about one-third that of conventional collagen fibrils; hence we likened them to the short-period collagen fibrils with a periodicity of 21$22 \mathrm{~nm}$ reported by Porter (1952) from chick fibroblast cultures, and by Gross (1956) from in vitro experiments with collagen solutions. According to this interpretation, we pictured the interpalisadal partitions of the shark's tooth as a primitive type of connective tissue, produced hy odontoblastic processes protruding into the enamel layer. We believed that the enameline fibrils of the mineralizing zones were a different type of product, probably derived from ameloblasts.

Although the above interpretation may be correct, we must consider two principal alternatives. It is conceivable first that all three types of fibres in the enamel layer-enameline fibrils, interpalisadal unit fibrils and giant fibres are products of odontoblast cells of the dental papilla. The second alternative is that all the fibrous components of the matrix are products of ameloblasts. According to this view, ameloblast secretions traverse the basement membrane and infiltrate between dental papilla cells. thereby filling the space between odontoblast processes as the enamel layer thickens. This hypothesis would hold that odontoblast processes protruding into the enamel layer secrete none of the fibrous components of the matrix.

Re-examination of our original hypothesis has caused us to question seriously whether giant fibres are indeed collagenous. Their banding periodicity of $14.5 \mathrm{~nm}$ is actually considerably less than a third that of conventional $(64 \mathrm{~nm})$ collagen fibrils; thus we are not justified in assuming that they are like the shortperiod collagenous fibrils described by Porter (1952) or Gross (1956). Complicating analysis of the histogenesis of giant fibres is their relation to the interpalisadal unit fibrils. Our first assumption was that these unit fibrils are collagenous, because they develop in the matrix between odontoblastic processes extending into the tooth cap. They surround the giant fibres, run in the same direction and unquestionably merge with the giant fibres. Unit fibrils and giant fibres are apparently different stages of polymerization of the same precursor substance.

Toward the base of the tooth the matrix of odontoblasts and pulpal cells contains conventional collagen fibrils. Likewise dentine contains conventional fibrils. Deep within the enamel layer, there appears to be a zone of overlap where giant fibres and conventional collagen fibres lie side by side in the matrix. In such locations there appears to be fusion of the two types, therehy supporting the concept that the giant fibres are collagenous. Morphological evidence argues against the possibility that unit fibrils and giant fibres of the interpalisadal zones are composed of enameline protein. The enameline fibrils are hollow. whereas the interpalisadal fibres are solid aggregations of protofibrils. Moreover, the enameline fibrils prior to mineralization are all about the same diameter in contrast to the variable diameters of interpalisadal fibrils and fibres. We conclude that the giant fibres and associated fibrils are probably not enameline protein but probably are collagenous. Further research will be necessary to establish their identity and to explain their unusual banding pattern.

Acknowledgements- This paper is Contribution No. 440 of the Hawaii Institute of Marine Biology. University of Hawaii, with support from an Atomic Energy Commission institutional grant for operation of the Eniwetok Marine Biological Laboratory. Eniwetok. Marshall Islands. The work 
ras further supported by grants from the National Science Foundation (GB 4317), the U.S. Public Health Service (AM 13745-01-05), and the University of Michigan Cancer Research Institute (Project 102 and SOMCR-PP 31).

We are grateful to the following individuals now or formerly at the University of Hawaii, who provided knowledge, space, supplies and equipment for this project while the senior investigator was on sabbatical leaves in 1965 and 1972: Professors R. D. Allen, J. E. Bardach, the late V. E. Brock, W. A. Gosline, R. W. Hiatt, H. Hohl, F. I. Kamemoto, T. A. Rogers and Dr. P. Helfrich. We are particularly indebted to Sergeant $\mathrm{S}$. Bass who caught and donated several small sharks while the senior investigator was at the Eniwetok Marine Laboratory in May, 1965. We thank Professor J. N. Cather, The University of Michigan, for photographic assistance, and Miss M. A. Susko (now Mrs Drnevich) and Mrs. B. J. Christian for technical assistance.

\section{REFERENCES}

Allan J. H. 1967. Maturation of enamel. In: Structural and Chemical Oryanization of Teeth (Edited by Miles A. E. W.), Vol. 1, pp. 467-494. Academic Press, New York.

Bargmann W. 1937. Zur Frage der Homologisierung von Schmelz und Vitrodentin. Z. Zellforsch. mikrosk. Anat. 27, $492-499$.

Carlström D. 1964. Polarization microscopy of dental enamel with reference to incipient carious lesions. Adv. oral Biol. 1, 255-296.

Daniel J.F. 1934. The Elasmobranch Fishes. University of California Press, Berkeley.

Fearnhead R. W. 1961. Electron microscopy of forming enamel. Archs oral Biol. Special Supplement, 4, 24-28.

Frank R. M. 1966. Étude an microscope electronique de l'odontoblaste et du canalicule dentinaire humain. Archs oral Biol. 11, 179-199.

Frank R. M. and Nalbandian J. 1967. Ultrastructure of amelogenesis. In: Structural and Chemical Organization of Teeth (Edited by Miles A. E. W.). Vol. 1. pp. 399-466. Academic Press, New York.

Frank R. M., Sognnaes R. F. and Kern R. 1960. Calcification of dental tissues with special reference to enamel ultrastructure. In: Calcification in Biological Systems (Edited by Sognnaes R. F.), pp. 163-202. American Association for the Advancement of Science, Washington D.C., U.S.A.

Frazier P. D. 1968. Adult human enamel : an electron microscopic study of crystallite size and morphology. J. Ultrastruct. Res. 22, 1-11.

Garant P. R. 1970. An electron microscopic study of the crystal-matrix relationship in the teeth of the dogfish Squalus acanthias. J. Ultrastruct. Res. 30, 441-449.

Glas J. E. 1962. Studies on the ultrastructure of dental enamel. VI. Crystal chemistry of shark's teeth. Odont. Revy 13, 315-326.

Glas J. E. and Omnell K. A. 1960. Studies on the ultrastructure of dental enamel-I: size and shape of the apatite crystallites as deduced from X-ray diffraction data. $J$. Ultrastruct. Res. 31, 334-344.

Glimcher M. J.. Travis D. F.. Friberg U. A. and Mechanic G. L. 1964. The electron microscopic localization of the neutral soluble proteins of developing bovine enamel. $J$. Ultrastruct. Res. 10, 362-376.

Grady J. E. 1970. Tooth development in sharks. Archs oral Biol, 15, 613-619.
Gross J. 1956. The behavior of collagen units as a model in morphogenesis. J. Biophys. Biochem. Cytol, Supplement 2 , $261-274$.

Gustafson G. and Gustafson A. G. 1967. Microanatomy and histochemistry of enamel. In: Structural and Chemical Organization of Teeth (Edited by Miles A. E. W.), Vol. 2. pp. 75-134. Academic Press New York.

Hertwig O. 1874. Ueber Bau und Entwickelung der Placoidschuppen und der Zähne der Selachier. Jena. Z Nulurw. 8, 331-404.

Jaekel O. 1891. Ueber die Gattung Pristiophorus. Arch. Naturgesch. 57, 15-48.

Jessen H. 1968. Elliptical tubules as unit structure of form ing enamel matrix in the rat. Archs oral Biol. 13, 351-352.

Kallenbach E. 1970. Fine structure of rat incisor enamel organ during late pigmentation and regression stages. $J$. Ultrastruct. Res. 30, 38-63.

Kallenbach E. 1971. Electron microscopy of the differentiating rat incisor ameloblast. J. Ultrastruct. Res. 35, 508531.

Kemp N. E. and Hoyt J. A. 1969. Sequence of ossification in the skeleton of growing and metamorphosing tadpoles of Rana pipiens. J. Morph. 129, 415-444.

Kemp N. E. and Park J. H. 1969. Fine structure of enamel and collagen in the crown of mineralizing teeth of the shark Carcharhinus menisorrah. Anat. Rec. 163, 210. Abstract.

Kemp N. E. and Park J. H. 1970. Regeneration of lepidotrichia and actinotrichia in the tailfin of the teleost Tilapia mossambica. Devl Biol. 22, 321-342.

Kerr T. 1955. Development and structure of the teeth in the dog fish Squalus acanthias (L.) and Scyliorhinus caniculus (L.). Proc. zool. Soc. Lond. 125, 95-114.

Kvam T. 1950. The Development of Mesodermal Enamel on Piscine Teeth. Aktietrykkeriet Trondhjem, Trondheim.

Lester K. S. 1970. On the nature of "ffibrils" and tubules in developing enamel of the opossum Didelphia marsupialis. J. Ultrastruct. Res. 30, 64-67.

I.evine P. T. Glimcher M. I. Seyer I. M., Huddleston J. I and Hein J. W. 1966. Noncollagenous nature of the proteins of shark enamel. Science 154, 1192-1193.

Lison L. 1949. Recherches sur l'histogenèse de l'émail dentaire chez les Sélaciens. Archs Biol.. Paris 60, 111-135.

Moss M. L. 1968. Bone, dentine and enamel and the evolution of vertebrates. In: Biology of the Mouth (Edited by Person, P.), pp. 37-65. American Association for the Advancement of Science, Washington D.C., U.S.A.

Moss M. L., Jones S. J. and Piez K. A. 1964. Calcified ectodermal collagens of shark tooth enamel and teleost scale. Science $145,940-942$.

Mummery J. H. 1917. On the structure and development of the tubular enamel of the Sparidae and Labridae. Phil. Trans. R. Soc. (B) 208, 251-269

Nylen M. U., Eanes E. D. and Omnell K. A. 1963. Crystal growth in the rat. $J$. cell Biol. 18, 109-123.

Orvig T. 1951. Histologic studies of placoderms and fossil elasmobranchs -I: the endoskeleton, with remarks on the hard tissues of lower vertebrates in general. Ark. Zool. 2, 321454.

Orvig T. 1967. Phylogeny of tooth tissue : evolution of some calcified tissues in early vertebrates. In: Structural and Chemical Organization of Teeth (Edited by Miles A. E. W.), Vol. 1. pp. 45-110. Academic Press, New York.

Owen R. 1840-1845. Odontography, or a Treatise on the Comparative Anatomy of the Teeth; their Physiological Relarions, Mode of Development and Microscopic Struc- 
ture in the Vertebrate Animals. Hippolyte Bailliere, London.

Pautard F. G. E. 1961. Studies of enamel and baleen. J. dent. Res. 40, 1285-1286. Abst.

Peyer B. 1968. Comparative Odontology (Translated and edited by Zangerl R.), The University of Chicago Press, Chicago.

Piez K. A. 1962. Chemistry of the protein matrix of enamel. In: Fundamentals of Keratinization (Edited by Butcher E. O. and Sognnaes R. F.), pp. 173-184. American Association for the Advancement of Science, Washington D.C., U.S.A.

Poole D. F. G. 1967. Phylogeny of tooth tissues: enameloid and enamel in recent vertebrates, with a note on the history of cementum. In: Structural and Chemical Organization of Teeth (Edited by Miles A. E. W.), pp. 111-149. Academic Press, New York.

Porter K. R. 1952. Repair processes in connective tissues. In: Connective Tissues (Edited by Ragan C.), pp. 126-158. Trans. 2nd Conf., Josiah Macy, Jr. Foundation, New York.

Reith E. J. 1970. The stages of amelogenesis as observed in molar teeth of young rats. J. Ultrastruct. Res. 30, 111-151.

Ripa L. W., Gwinnett A. J., Guzman C. and Legler D. 1972. Microstructural and microradiographic qualities of lemon shark enameloid. Archs oral Biol. 17, 165-173

Rönnholm E. 1962a. An electron microscopic study of the amelogenesis in human teeth-I: the fine structure of the ameloblasts. J. Ultrastruct, Res. 6, 229-248.

Rönnholm E. 1962b. The amelogenesis of human teeth as revealed by electron microscopy--II: the development of the enamel crystallites. J. Ultrastruct. Res. 6, 249-303.

Ronnholm E. 1962c. The amelogenesis of human teeth as revalcd by electron microscopy--III: the structure of the organic stroma of human enamel during amelogenesis. $J$. L/trastruct. Res. 6, 368- 389.

Röse C. 1898. Ueber die verschiedenen Abänderungen der Hartgewebe bei niederen Wirbeltieren. Anat. Anz. 14, 21 3 I and 33-69.

Salomon C. D. 1969. Dentin of Carcharhinus milberti (shark): a comparative histological and histochemical study. $J$. de'nt. Res. 40, 49-55.
Sasso W. Da S. and Santos H. De S. 1961. Electron microscopy of enamel and dentin of teeth of the Odontaspis (Selachii). J. dent. Res. 40, 49-55.

Schmidt W. J. 1940. Polarisationsoptische Untersuchung schmelzartiger Aussenschichten des Zahnbeins von Fischen. II. Das porzellanartige Dentin (Durodentin) der Selachier. Z. Zellforsch. mikrosk. Anat. 30, 235-272.

Souza H. De S. and Sasso W. Da S. 1961. Electron diffraction and electron microscopy studies on the crystalline component of enamel of the Odontaspis (Selachii). Experientia 17, 17-19.

Thomasset J. J. 1930. Recherches sur les tissus dentaires des poissons fossiles. Archs Anat. Histol. Embryol. 11, 5- 153.

Tomes C. S. 1897. On the development of marsupial and other tubular enamels, with notes upon the development of enamel in general. Phil. Trans. R. Soc. (B) 189, 107-122.

Tomes C. S. 1898. Upon the structure and development of the enamel of elasmobranch fishes. Phil. Trans. R. Soc. (B) $190,443-464$.

Trautz O.R., Klein E. and Addelston H. K. 1952. Variations in the X-ray diffractograms of dental enamel of man and shark. J. dent. Res. 31, 472-473.

Travis D. F. 1968. Comparative ultrastructure and organization of inorganic crystals and organic matrices of mineralized tissues. In: Biology of the Mouth (Edited by Person P.), pp 237-297. American Association for the Advancement of Science, Washington D.C., U.S.A.

Veis A., Spector A. R, and Carmichael D. J. 1969. The organization and polymerization of bone and dentin collagens. Clin. Orthop. 66, 188-211.

Warshawsky H. 1971. A light and electron microscopic study of the nearly mature enamel of rat incisors. Anat. Rec. 169, 559-584.

Weidenreich F. 1926. Uber den Schmelz der Wirbeltiere und seine Beziehungen zum Zahnbein (Knochenstudien $\mathrm{V}$. Teil). Z. Anat. EntwGesch. 79, 292-351.

Weinstock A. and Leblond C. P. 1971. Elaboration of the matrix glycoprotein of enamel by the secretory ameloblasts of the rat incisor as revealed by autoradiography after galactose- ${ }^{3} \mathrm{H}$ injection. J. cell Biol. 51, 26-51.

Résumé- Les deux premières rangées de dents, à l'extrémité postérieure de la lame dentaire de Carcharhinus menisorrah, long de $60 \mathrm{~cm}$, ne sont pas calcifiées, mais la calcification a commencé au niveau de la couche périphérique au sommet des dents de la troisième rangée. Les cristaux d'émail se développent à l'intérieur de fibrilles creuses (tubules) d'énameline, qui polymérisent sous la membrane basale située près des améloblastes. Des vésicules contenant de fines granules sont présentes dans le cytoplasme apical des améloblastes des bourgeons dentaires avant calcification. Un matériel granulaire fin extracellulaire s'accumule entre améloblastes et membrane basale et aussi dans la matrice d'énameline du côté pulpaire de la membrane basale. La morphologie suggère que les améloblastes secrètent un précurseur granulaire des fibrilles d'énameline. Les cristaux d'émail avec leur revêtement fibreux sont étroitement groupés dans les zones en voie de minéralisation. Les crịstaux deviennent très longs et équillatéralement héxagonaux en coupe transversale. Ils sont disposés parallèlement dans des faisceaux de fibrilles dans les zones en voie de minéralisation. Les cristaux deviennent très longs et équilatéralement héxagonaux en coupe pénètrent dans la couche périphérique entre des zones minéralisées. Des fibres géantes avec une périodicité transversale de $14,5 \mathrm{~nm}$ sont visibles dans la matrice en voie de développement entre les zones de minéralisation. Leur origine et nature n'ont pu être déterminées. Des fibrilles collagènes typiques se développent dans le tissu conjonctif de la base de la dent et dans la dentine. Les cristaux de la dentine sont en forme d'aiguilles comme chez les mammifères. La couche périphérique des dents de requins est supposée être constituée d'émail tubulaire, où les zones minéralisées sont analogues à l'émail mammalien, mais qui est perméabilisé par des prolongements odontoblastiques d'origine més odermique. 
Zusammenfassung-Bei einem $60 \mathrm{~cm}$ langen Carcharhinus menisorrah waren die ersten beiden Zahnreihen am posterioren Ende der Zahnleiste unverkalkt, jedoch hatte die Verkalkung an den Spitzen der Schmelzkappen der dritten Zahnreihe begonnen. Schmelzkristallite entwickelten sich innerhalb hohler Schmelzfibrillen (Tubuli), welche sich unter der Basalmembran der darunterliegenden Ameloblasten zusammenlagerten. Bläschen mit feingranulärem Inhalt waren im apikalen Zytoplasma der Ameloblasten von Zahnkeimen vor der Kalzifikation vorhanden. Das feingranuläre Material sammelte sich extrazellulär zwischen den Ameloblasten und der Basalmembran, aber auch in der Enamelin-Matrix auf der pulpalen Seite der Basalmembran an. Der morphologische Befund deutet darauf hin, daß die Ameloblasten Bausteine für die mineralisierenden Enamelin-Fibrillen ausscheiden. Die Schmelzkristallite waren mit ihren fibrösen Bedeckungen in den Mineralisationszonen eng zusammengelagert. Die Kristallite werden unbestimmt lang und im Querschnitt gleichförmig hexagonal. Sie waren innerhalb der in den Mineralisationszonen verwobenen Fibrillenbündel parallel angeordnet. Odontoblastenfortsätze und markhaltige Nervenfasern reichten bis in die Deckschicht zwischen den mineralisierenden Zonen. Riesenfasern mit einer Bandperiodizität von 14.5 nm traten in der beteiligten Matrix zwischen den Mineralisationszonen auf. Deren Herkunft und Natur war unklar. Normale Kollagenfasern entwickelten sich im Bindegewebe innerhalb der Basis des Zahnes sowie im Dentin, sobald dies zu differenzieren beginnt. Kristallite des mineralisierten Dentins waren wie bei Säugetieren nadelförmig. Die Kappenschicht des Haifischzahnes dürfte aus tubulärem Schmelz bestehen, in welchem die mineralisierten Zonen wahrscheinlich dem Säugetierschmelz entsprechen, obwohl er von Odontoblastenfortsätzen mesodermaler Herkunft durchdrungen wird.

Plate 1

Fig. 1. Lateral view of an excised block from the lower jaw of Carcharhinus menisorrah, showing a single file of the eight rows of teeth exposed after removal of the covering tissue of the dental pocket. The first two teeth primordia at the posterior end of the file are soft and uncalcified. The third-row tooth (arrow) has begun to calcify around its tip. The fourth-row tooth is more calcified, and the more anterior four teeth are heavily calcified. $\times 5$

Fig. 2. Photomicrograph of dental lamina (dl) and primordia from first two rows of teeth $\left(t_{1}, t_{2}\right)$. The earliest primordium $\left(t_{1}\right)$ is mound-shaped. The second-row tooth $\left(t_{2}\right)$ has elongated to cone shape. a, ameloblasts; e, enameline matrix; dp, dental papilla. Heidenhain's azan. $\times 84$

Fig. 3. Section of apex of a third-row tooth in which calcification of the enameline matrix (e) has commenced. Ameloblasts (a) are tall, columnar cells. Pink-staining odontoblastic processes from peripheral cells of the dental papilla (dp) extend into the enameline matrix and tend to curve toward the tip. Bluestaining fibres are oriented perpendicular to the tooth surface within the enameline matrix. Heidenhain's azan. $\times 84$

Fig. 4. Section showing bases of third- and fourth-row teeth $\left(t_{3}, t_{4}\right)$. Thickness of enameline matrix (e) diminishes toward the tooth base as the height of the ameloblastic layer lessens. Odontoblasts (o) form a layer at the periphery of the dental papilla (dp). Dentine (d) has developed in the base and beneath the basal enamel of the fourth-row tooth. Heidenhain's azan. $\times 84$ 
Ultrastructure of shark enamel layer

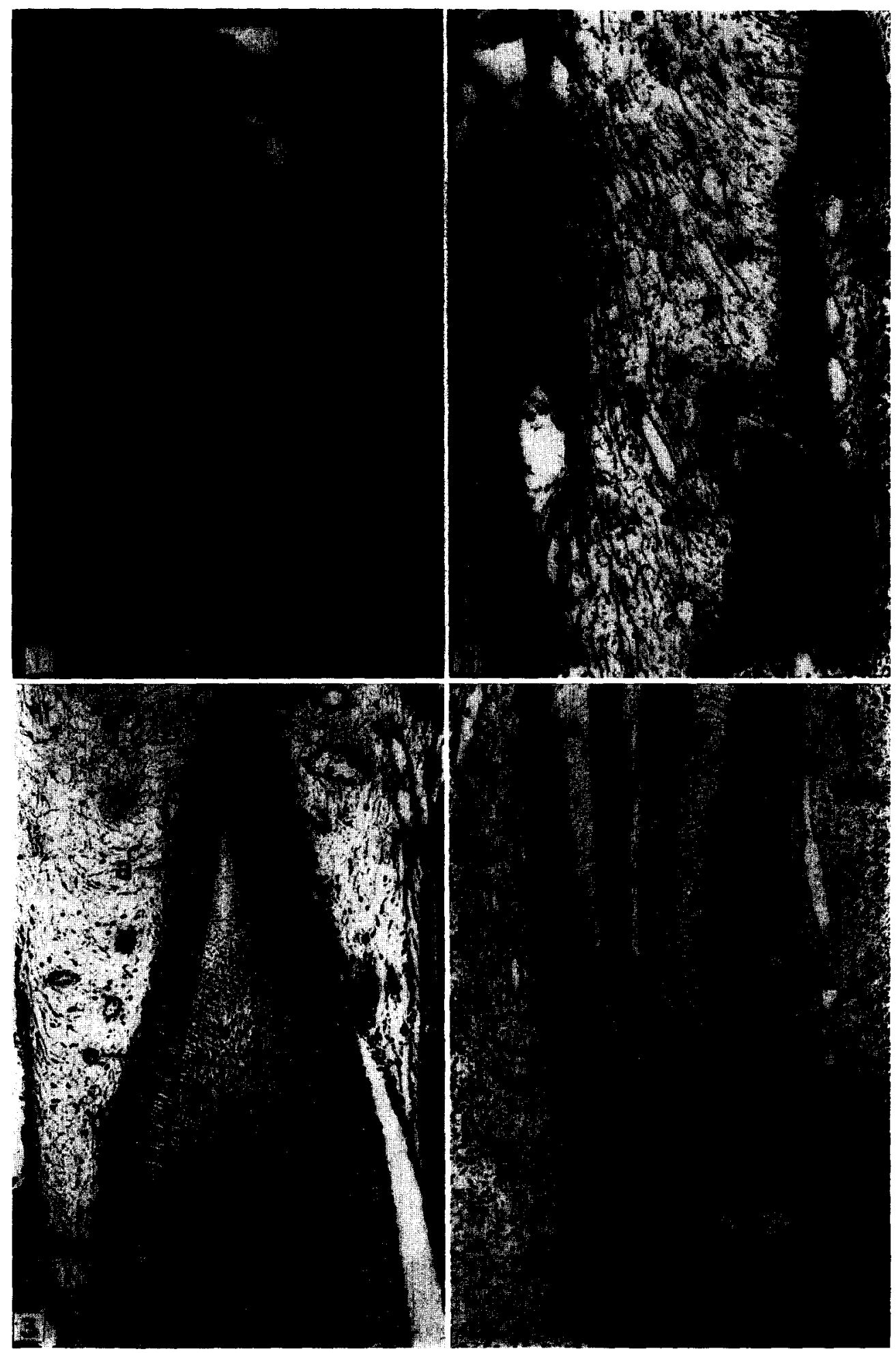

Plate 1

A.O.B f.p. 640 
N. E. Kemp and J. H. Park

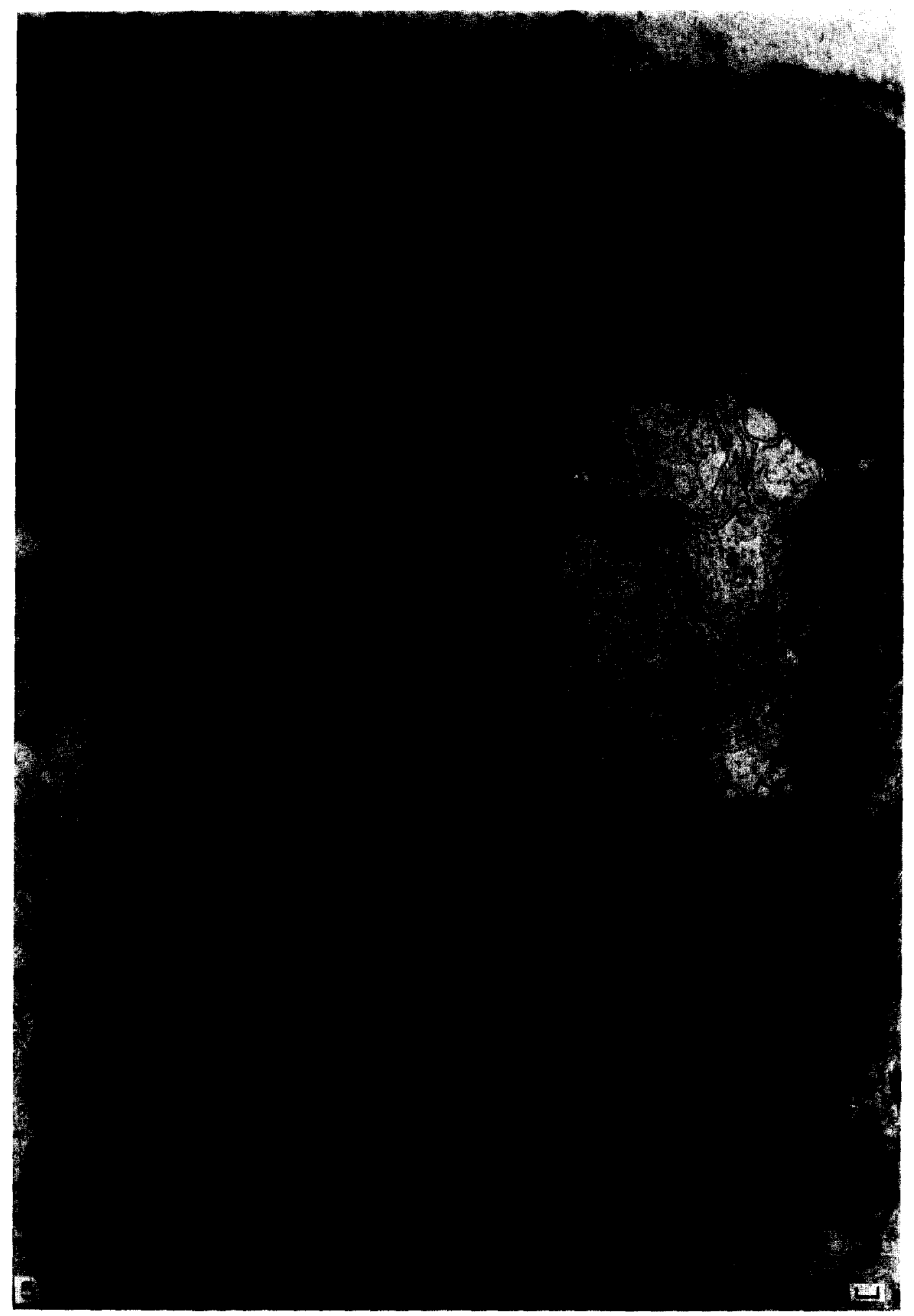

Plate 2 
Plate 2

Fig. 5. Electron micrograph of mineralized enamel at the periphery of a developing tooth. Long enamel crystals of the mineralized zones run parallel to one another. Between mineralized sectors. called palisades after the terminology of Garant, are interpalisadal zones containing unit fibrils ( $\mathrm{f}$ ) and giant fibres (gf) formed by fusion of unit fibrils. The cytoplasmic remnants within the mineralized palisade are from an odontoblast process penetrating the enamel layer. Bar in this and subsequent Figs. represents $0.1 \mu \mathrm{m}$. $\times 31000$ 


\section{Plate 3}

Fig. 6. Section of a non-mineralized tooth showing the apical ends of ameloblasts (a), the underlying basement membranc (bm), matrix of presumptive enamel layer, and portion of a papilla cell ( $\mathrm{pc}$ ) of the dental papilla. Cytoplasm of the apical ends of ameloblasts contains vesicles (v) with finely granular contents. Unit fibrils (f) and giant fibre (gf) mark the location of a future interpalisadal zone. To the right of the giant fibre is a fibrous matrix which is precursor to a mineralizing palisade. In this zone between basement membrane and papilla cells are fine fibrils (arrows) thought to be developing enameline fibrils. $\times 62000$

Fig. 7. Section showing early stage of mineralization of enamel. Apical borders of ameloblasts (a) are folded to form apical crypts (ac). Apical cytoplasm of ameloblasts contains apical vesicles (v) with dense granular contents. Region of apparent fusion between an apical vesicle and the base of an apical crypt is shown at arrow. Dense granular material has accumulated in the apical crypts between ameloblasts and basement membrane (bm). Closely packed bundles of enameline fibrils (ef) have formed in the enameline matrix and crystals of enamel (c) have begun to grow within many hollow fibrils (tubules). 


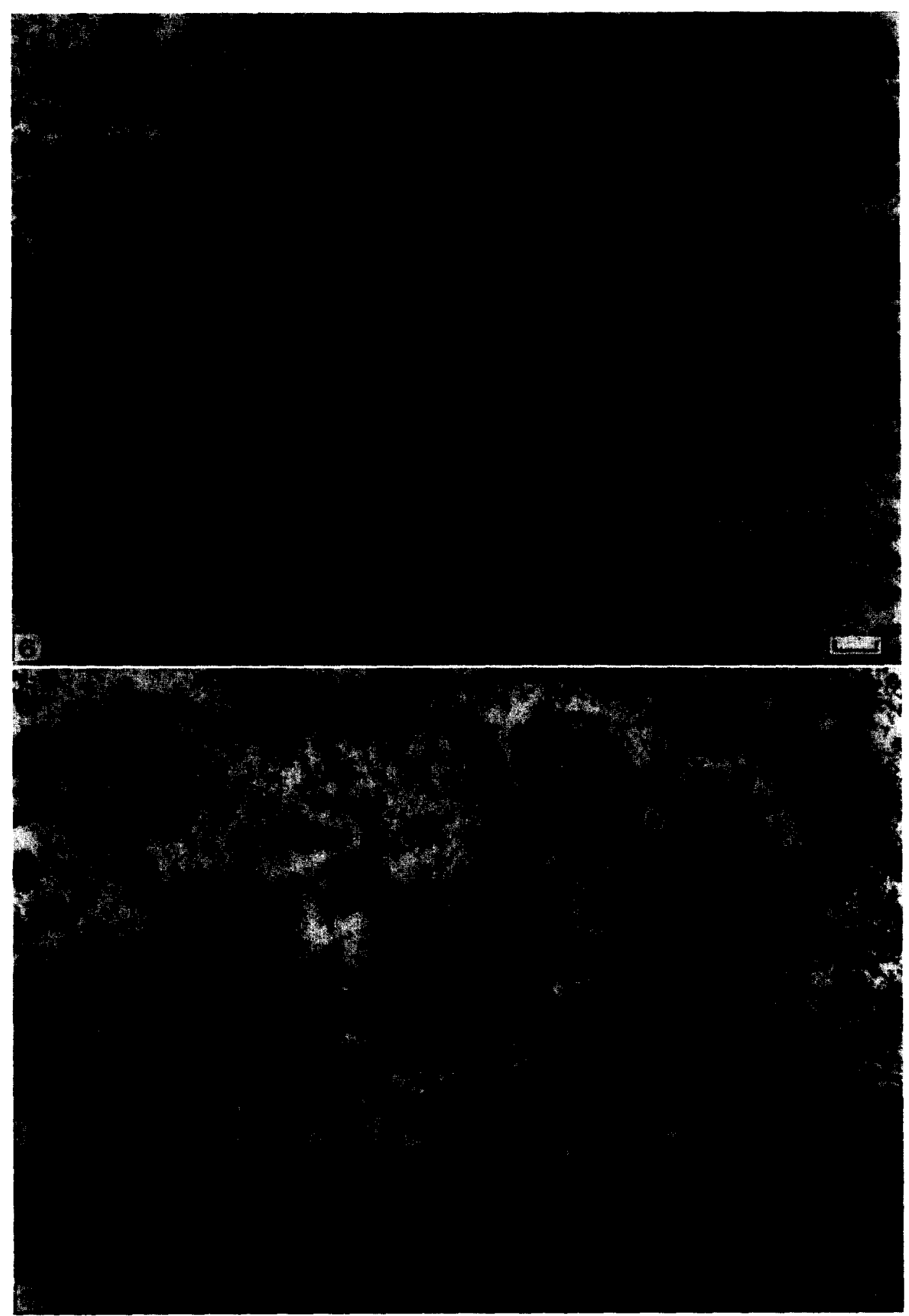

Plate 3

A.O.B. f.p. 642 
N. E. Kemp and J. H. Park

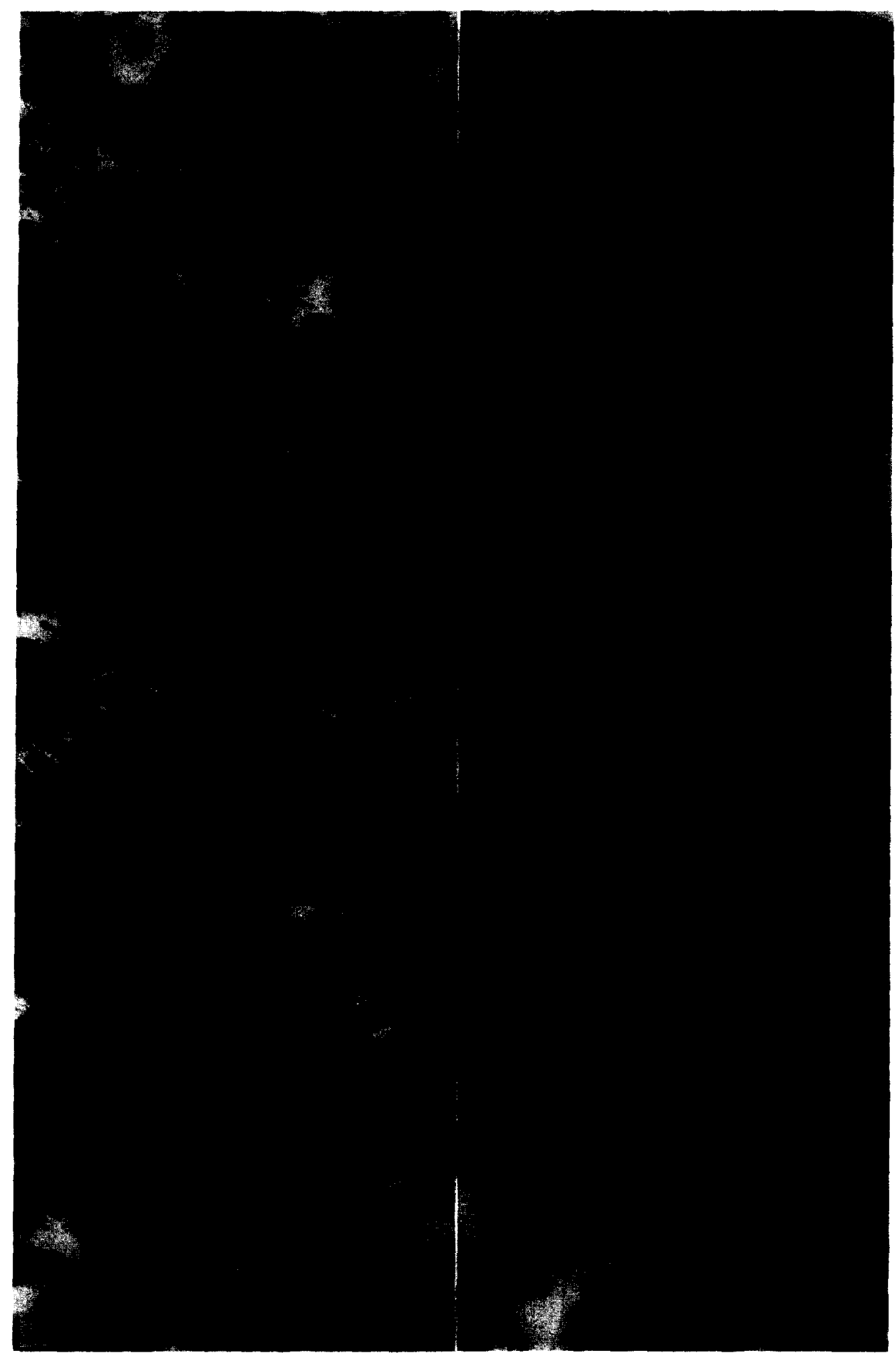

Plate 4 


\section{Plate 4}

Fig. 8. Enlargement of a mineralizing zone at the stage illustrated in Fig. 7. Enamel crystals are developing within the interior of individual enameline fibrils (tubules). Cross sections of enameline fibrils show granular subunits (arrow) $\times 147000$

Fig. 9. Enlargement showing stages of growth of enamel crystals in growing tooth. Most of the crystals are oriented longitudinally. They vary in width in this specimen from $7.0 \mathrm{~nm}\left(\mathrm{c}_{1}\right)$ to $46.5 \mathrm{~nm}\left(\mathrm{c}_{2}\right)$ and are of indefinite length. $\times 68400$ 


\section{Plate 5}

Fig. 10. Enlargement showing enamel crystals of growing tooth. many of them oriented in cross section. The larger crystals are equilaterally hexagonal (arrow). Interpalisadal matrix is occupied by cytoplasmic remnants of odontoblast processes and by fibres of various sizes. The giant fibre $\left(\mathrm{g} f_{1}\right)$ in longitudinal section shows a banding periodicity of $14.5 \mathrm{~nm}$. Protofibrils within giant fibres can be seen clearly in cross sections $\left(\mathrm{gf}_{2}\right) \times 65500$

Fig. 11. Enlargement of giant fibre in the enamel layer of a mineralizing tooth. The banding periodicity is $14.5 \mathrm{~nm}$. The apparently wider banding periodicity at lower left is irregular and may be an artifact.

$$
\times 93500
$$




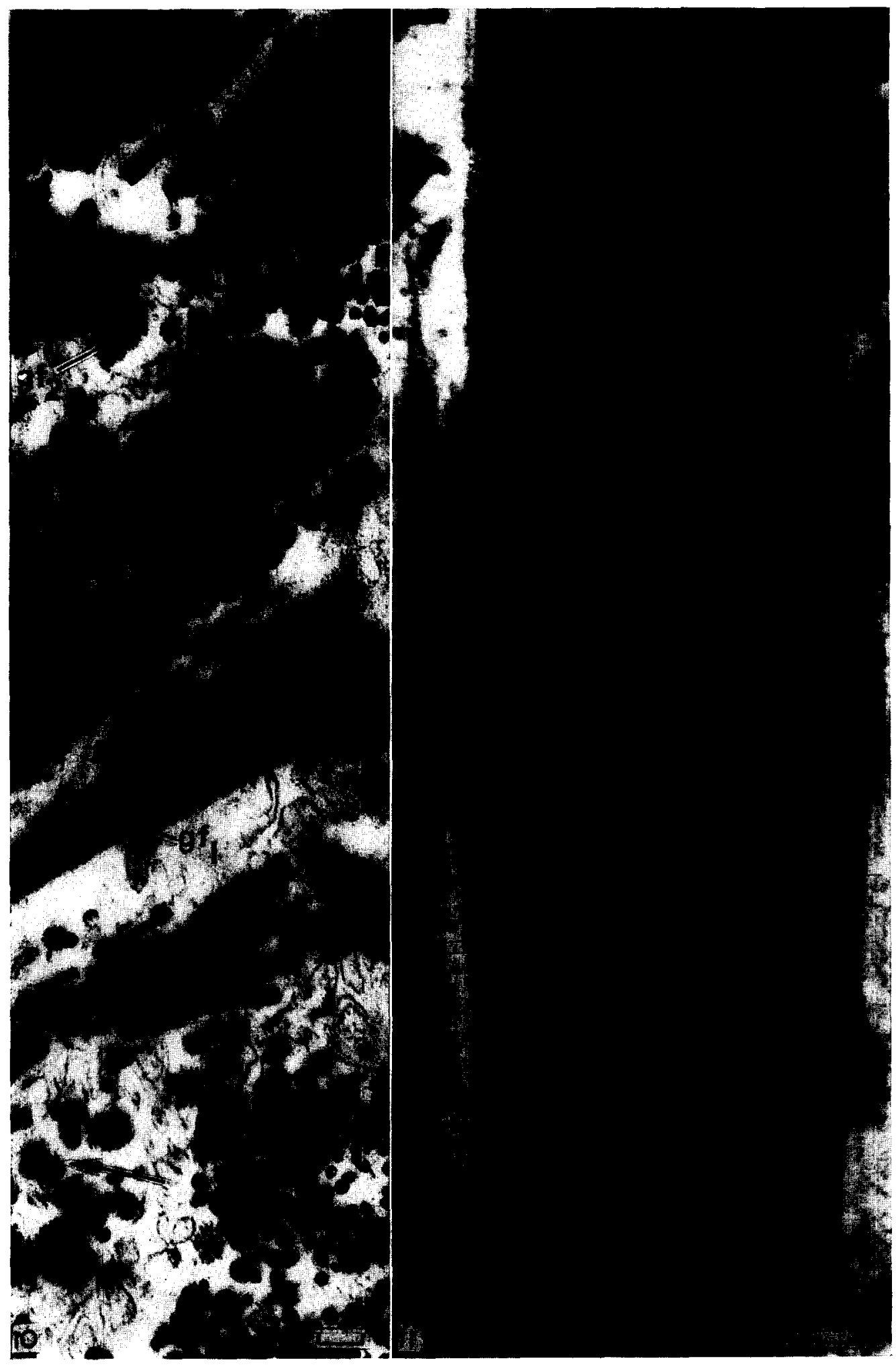

